\title{
HUBUNGAN TEKANAN DARAH DAN LAMA MENDERITA DIABETES DENGAN LAJU FILTRASI GLOMERULUS PADA SUBJEK DIABETES MELITUS TIPE 2
}

\author{
${ }^{1}$ Nurmalasari Amira \\ ${ }^{2}$ Karel Pandelaki \\ ${ }^{2}$ Stella Palar \\ ${ }^{1}$ Kandidat Skripsi Fakultas Kedokteran Universitas Sam Ratulangi Manado \\ ${ }^{2}$ Bagian Ilmu Penyakit Dalam Fakultas Kedokteran Universitas Sam Ratulangi Manado \\ Email: nurmalasariamira@yahoo.co.id \\ kpandelaki@yahoo.com \\ palarstella@yahoo.com
}

\begin{abstract}
Diabetes Mellitus Type 2 is a metabolic disease that has been a problem in regards of world health. In Indonesia, the prevalence and incident of this disease keeps on increasing with each passing year. The increasing of blood pressure, more often than not, accompanies the case of diabetes mellitus. This causes the increase of both morbidity and mortality rate because it increases the risk of complications, in both macro-vascular and micro-vascular, one of which is nephropathy diabetic. Purpose: This research is aimed in understanding the correlation between blood pressure and the amount of period of suffering diabetes with glomerulus filtration rate in subject with diabetes mellitus type 2. Methods: The research method used is analytic descriptive with cross sectional approach using secondary data. The amount of sample is 152 patients of diabetes mellitus type 2, who came for treatment in Polyclinic Endocrine and Metabolic RSUP Prof. Dr. R. D. Kandou, Manado, during the period of November to December 2013. Conclusion: The result of the analysis using spearman's correlation shows that there is a substantial correlation between blood pressure and glomerulus filtration rate $(p=0,000)$ with negative direction, which means that the higher one's blood pressure, the lower one's glomerulus filtration rate is. Also, there is no substantial correlation regarding the period of suffering diabetes $(p=0,971)$, because the glomerulus filtration rate doesn't only depends on how long someone has been having diabetes, and instead there are another factors that are influencing the kidney's function, for example: hypertension.
\end{abstract}

Keywords: blood pressure, glomerulus filtration rate, diabetes mellitus type 2

\begin{abstract}
Abstrak: Diabetes Melitus tipe 2 merupakan penyakit metabolik yang telah menjadi masalah kesehatan dunia. Indonesia prevalensi dan insiden penyakit ini terus meningkat dari tahun ke tahun. Peningkatan tekanan darah sering menyertai penyakit diabetes melitus. Hal ini meningkatkan morbiditas dan mortalitas karena meningkatkan resiko terjadinya komplikasi baik makrovaskular dan mikrovaskular diantaranya nefropati diabetik. Tujuan: Penelitian ini bertujuan untuk mengetahui hubungan tekanan darah dan lama menderita diabetes dengan laju filtrasi glomerulus pada subjek diabetes melitus tipe 2. Metode: Jenis penelitian yang digunakan adalah deskriptif analitik dengan pendekatan cross sectional menggunakan data sekunder. Jumlah sampel sebanyak 152 pasien diabetes melitus tipe 2 yang berobat di Poliklinik Endokrin dan Metabolik RSUP Prof. Dr. R. D. Kandou Manado periode November - Desember 2013. Simpulan: Hasil analisis menggunakan spearman's correlation menunjukkan bahwa ada hubungan yang bermakna antara tekanan darah dengan laju filtrasi glomerulus $(p=0,000)$ dengan arah hubungan negatif yakni semakin tinggi tekanan darah
\end{abstract}


maka filtrasi glomerulus semakin rendah, serta tidak ada hubungan bermakna dengan lama menderita diabetes ( $\mathrm{p}=0,971$ ) oleh karena laju filtrasi glomerulus tidak hanya bergantung pada lamanya menderita diabetes melainkan ada faktor lain yang mempengaruhi fungsi ginjal misalnya hipertensi.

Kata kunci: Tekanan darah, laju filtrasi glomerulus, diabetes melitus tipe 2

Diabetes Melitus (DM) merupakan suatu kelompok penyakit metabolik dengan karakteristik hiperglikemia yang terjadi karena kelainan sekresi insulin, kerja insulin, atau kedua-duanya. ${ }^{1}$ Secara epidemiologis, DM seringkali tidak terdeteksi dan dikatakan onset atau mulai terjadinya diabetes adalah tujuh tahun sebelum diagnosis ditegakkan, sehingga morbiditas dan mortalitas dini terjadi pada kasus tidak terdeteksi. ${ }^{2}$ Berbagai penelitian menunjukkan adanya kecenderungan peningkatan angka insidensi dan prevalensi DM tipe 2 diberbagai penjuru dunia. WHO memprediksi adanya peningkatan jumlah penyandang diabetes yang cukup besar pada tahun mendatang. WHO memprediksi kenaikan jumlah penyandang DM di Indonesia dari 8,4 juta pada tahun 2000 menjadi sekitar 21,3 juta pada tahun 2030. ${ }^{3}$ Senada dengan WHO, Internasional Diabetes Federation memprediksi bahwa jumlah orang yang hidup dengan diabetes akan meningkat dari 366 juta orang pada 2011 menjadi 552 juta orang pada tahun 2030. ${ }^{4}$ Data dari National Diabetes Fact Sheet berdasarkan data tahun 2011 didapatkan bahwa angka kejadian DM adalah sebanyak 25,8 juta pada anak dan dewasa di Amerika Serikat atau 8,3\% dari populasi yang menderita diabetes. Sedang untuk prediabetes sebanyak 79 juta orang, kasus baru sebanyak 1,9 juta terdiagnosis pada usia lebih dari 20 tahun. $^{5}$

Menurut penelitian epidemiologi di Indonesia, kekerapan DM berkisar antara 1,4-1,6\%, kecuali didua tempat yaitu Pekajangan 2,3\% dan Manado 6\%. Penelitian antara tahun 2001 dan 2005 di daerah Depok didapatkan prevalensi DM tipe 2 sebesar 14,7\%, demikian juga di Makassar prevalensi terakhir tahun 2005 yang mencapai 12,5\%. ${ }^{6}$ Berdasarkan penelitian yang dilakukan Nadyah Awad pada November 2011, jumlah pasien yang berkunjung di Poliklinik Endokrin Metabolik RSUP Prof. Dr. R. D. Kandou Manado periode Mei-Oktober 2011 adalah sebanyak 3.998 pasien. Dari total 3.998 pasien tersebut didapatkan pasien baru yang menderita DM tipe 2 sebanyak 138 pasien yang terdiri dari 60 orang laki-laki (43\%) dan 78 orang perempuan $(53 \%){ }^{7}$

Prevalensi terjadinya hipertensi pada DM secara keseluruhan adalah $70 \%$, dimana pada laki laki 32 \% dan wanita 45 \%. Pada masyarakat India Puma prevalensi hipertensi sebesar 49\%, pada kulit putih sebanyak $37 \%$ dan orang asia sebesar 35\%. Hal ini menggambarkan bahwa hipertensi pada DM lebih sering terjadi daripada tidak menderita diabetes. Pada pasien DM, hipertensi biasanya disebabkan oleh nefropati diabetik yang berhubungan dengan peningkatan tekanan darah dan penurunan LFG, dimana telah dilaporkan terjadi pada $25-40 \%$ orang dengan DM tipe 1 dan 2. Peningkatan insidensi DM akan meningkatkan insidensi komplikasi. Dari berbagai penelitian didapatkan sebanyak 30-40\% penderita DM tipe 2 akan mengalami kerusakan ginjal yang pada akhirnya akan menjadi gagal ginjal terminal yang memerlukan hemodialisis. Orang dengan DM, khususnya yang melibatkan gangguan ginjal, akan terjadi peningkatan mortalitas dan morbiditas oleh kardiovaskular. Dengan meningkatnya insidensi DM tipe 2 maka secara signifikan akan meningkatkan pula insidensi gagal ginjal dan penyakit kardiovaskular. ${ }^{8}$

\section{METODE}

Penelitian ini merupakan penelitian dekskriptif analitik dengan pendekatan cross sectional menggunakan data sekunder. Tempat penelitian ini dilaksanakan di Poliklinik Endokrin dan Metabolik Bagian Ilmu Penyakit Dalam RSUP Prof. Dr. R. D. Kandou Manado dan waktu penelitian dilaksanakan pada bulan November - Desember 2013. Populasi yang 
diteliti adalah semua pasien yang berobat di Poliklinik Endokrin dan Metabolik RSUP Prof. Dr. R. D. Kandou Manado dan sampelnya yaitu pasien Diabetes Melitus tipe 2. Variabel penelitian terdiri dari variabel bebas yaitu tekanan darah dan lama menderita diabetes, serta variabel tergantung yaitu laju filtrasi glomerulus.

Pengumpulan data dilakukan dengan mengambil data rekam medik berupa usia, jenis kelamin, suku bangsa/ras, hasil lab serum kreatinin, lama menderita diabetes dan tekanan darah. Selanjutnya dihitung estimasi laju filtrasi glomerulus menggunakan formula Chronic Kidney Disease Epidemiology Collaboration (CKD-EPI). Analisis data dilakukan dengan analisis bivariat spearman's correlation menggunakan program komputer SPSS.

\section{HASIL}

Berdasarkan hasil analisis univariat karakteristik responden dalam penelitian ini meliputi jenis kelamin, usia, tekanan darah, lama menderita diabetes, dan laju filtrasi glomerulus. Untuk memperoleh gambaran distribusi karakteristik responden dapat dilihat pada tabel berikut:

Tabel 1. Distribusi Sampel berdasarkan Jenis Kelamin

\begin{tabular}{lcc}
\hline \multicolumn{1}{c}{ Jenis Kelamin } & n & Persen \\
\hline Perempuan & 93 & 61,1 \\
Laki - laki & 59 & 38,9 \\
Total & 152 & 100 \\
\hline
\end{tabular}

Jumlah pasien diabetes melitus tipe 2 yang didapatkan adalah 152 orang, terdiri atas 93 orang perempuan $(61,1 \%)$ dan 59 orang laki-laki (38,9\%).

Tabel 2. Distribusi Sampel berdasarkan Usia

\begin{tabular}{ccc}
\hline Usia (tahun) & n & Persen \\
\hline$<45$ & 6 & 3,94 \\
$>45$ & 146 & 96,06 \\
Total & 152 & 100 \\
\hline
\end{tabular}

Berdasarkan hasil penelitian jumlah subjek dengan usia $<45$ tahun sebanyak 6 orang (3,94\%) sedang untuk usia $>45$ tahun sebanyak 146 orang $(96,06 \%)$.

Tabel 3. Distribusi Sampel berdasarkan Tekanan Darah

\begin{tabular}{lcc}
\hline \multicolumn{1}{c}{ Kategori } & n & Persen \\
\hline Normal & 69 & 45,4 \\
Prehipertensi & 14 & 9,2 \\
Hipertensi Derajat 1 & 38 & 25,0 \\
Hipertensi Derajat 2 & 31 & 20,4 \\
Total & 152 & 100 \\
\hline
\end{tabular}

Berdasarkan hasil penelitian jumlah subjek dengan tekanan darah normal adalah 69 orang (45,4\%). Subjek dengan prehipertensi 14 orang (9,2\%). Sedangkan untuk subjek dengan hipertensi derajat 1 adalah 38 orang (25,0\%) dan hipertensi derajat 231 orang (20,4\%). 
Tabel 4. Distribusi Sampel berdasarkan Lama Menderita Diabetes

\begin{tabular}{ccc}
\hline (tahun) & n & Persen \\
\hline$<5$ & 55 & 36,2 \\
$5-15$ & 75 & 49,3 \\
$16-25$ & 14 & 9,2 \\
$26-35$ & 8 & 5,3 \\
Total & 152 & 100 \\
\hline
\end{tabular}

Berdasarkan hasil penelitian pada subjek untuk melihat lamanya menderita diabetes melitus tipe 2 didapatkan subjek dengan lama menderita $<5$ tahun adalah 55 orang (36,2\%). Subjek dengan lama menderita 5-15 tahun adalah 75 orang (49,3\%). Untuk lama 16-25 tahun didapatkan subjek 14 orang (9,2\%) dan 26-35 tahun sebanyak 8 orang (5,3\%).

Tabel 5. Distribusi Sampel berdasarkan Laju Fitrasi Glomerulus

\begin{tabular}{ccc}
\hline Derajat & n & Persen \\
\hline 1 & 18 & 11,8 \\
2 & 26 & 17,1 \\
3 & 51 & 33,6 \\
4 & 39 & 25,7 \\
5 & 18 & 11,8 \\
Total & 152 & 100 \\
\hline
\end{tabular}

Berdasarkan hasil penelitian didapatkan subjek dengan LFG normal atau meningkat (derajat 1) sebanyak 18 orang (11,8\%). Untuk subjek yang mengalami kerusakan ginjal dengan LFG menurun ringan (derajat 2) adalah 26 orang (17,1\%). Sedangkan subjek dengan kerusakan ginjal disertai LFG menurun sedang (derajat 3) dan berat (derajat 4) masingmasing sebanyak 51 orang (33,6\%) dan 39 orang (25,7\%). Dan untuk subjek dengan gagal ginjal (derajat 5) sebanyak 18 orang $(11,8 \%)$.

Tabel 6. Distribusi Tekanan Darah dan Laju Fitrasi Glomerulus

\begin{tabular}{lccccc}
\hline & & \multicolumn{4}{c}{ Tekanan Darah } \\
\cline { 2 - 6 } & Derajat & Normal & $\begin{array}{c}\text { Prehiper } \\
\text { tensi }\end{array}$ & $\begin{array}{c}\text { Hipertensi } \\
\text { Derajat 1 }\end{array}$ & $\begin{array}{c}\text { Hipertensi } \\
\text { Derajat 2 }\end{array}$ \\
\hline LFG & 1 & 14 & 2 & 2 & 0 \\
& 2 & 20 & 1 & 5 & 0 \\
3 & 17 & 7 & 26 & 1 \\
& 4 & 11 & 2 & 3 & 23 \\
& 5 & 7 & 2 & 2 & 7 \\
\multicolumn{2}{c}{ Total (152) } & 69 & 14 & 38 & 31 \\
\hline
\end{tabular}

Berdasarkan hasil penelitian didapatkan bahwa subjek terbanyak terdistribusi pada hipertensi derajat 1 dengan LFG derajat 3 sebanyak 26 orang. 
Tabel 7. Distribusi Lama Menderita Diabetes dan Laju Fitrasi Glomerulus

\begin{tabular}{lccccc}
\hline & & \multicolumn{4}{c}{ Lama Menderita DM (tahun) } \\
\cline { 3 - 6 } & Derajat & $<5$ & $5-15$ & $16-25$ & $26-35$ \\
\hline LFG & 1 & 9 & 4 & 3 & 1 \\
& 2 & 11 & 14 & 2 & 0 \\
& 3 & 10 & 32 & 5 & 3 \\
& 4 & 18 & 15 & 4 & 3 \\
Total (152) & 5 & 7 & 10 & 0 & 1 \\
\hline
\end{tabular}

Berdasarkan hasil penelitian didapatkan bahwa subjek terbanyak terdistribusi pada lama menderita diabetes 5-15 tahun dengan LFG derajat 3 sebanyak 32 orang.

Untuk mengetahui adanya hubungan tekanan darah dan lama menderita diabetes dengan LFG digunakan analisis bivariat spearman's correlation. Untuk tekanan darah dan LFG perolehan $\mathrm{p}$ hitung $=0,000<0,05$ yang menandakan bahwa ada hubungan yang bermakna dengan arah hubungan adalah negatif. Selain itu, antara lama menderita diabetes dengan LFG perolehan $\mathrm{p}$ hitung $=0,971>0,05$ yang menandakan bahwa tidak ada hubungan yang bermakna.

\section{BAHASAN}

Dari hasil penelitian mengenai hubungan tekanan darah dan lama menderita diabetes dengan LFG, subjek DM tipe 2 yang didapatkan adalah 152 orang, terdiri atas 93 orang perempuan (61,1\%) dan 59 orang laki-laki (38,9\%). Hal ini sejalan dengan penelitian Siti Chodijah dimana dari 27 orang penderita DM dengan sepsis terdapat 23 orang (85\%) perempuan dan 4 orang (15\%) laki-laki. ${ }^{9}$ Selain itu penelitian ini juga sejalan dengan penelitian di Amerika yang menunjukkan bahwa angka kejadian diabetes pada perempuan lebih tinggi yaitu 7,3\% dibandingkan laki-laki sebesar 5,8\% pada orang kulit putih, sedangkan pada orang kulit hitam didapatkan perempuan sebesar 11\% dan laki-laki 7,8\%. Selain itu lebih banyaknya perempuan yang menderita DM tipe 2 ini bisa disebabkan oleh faktor risiko seperti obesitas, kurang aktifitas fisik, riwayat diabetes gestasional dan sindrom ovarium polikistik (yang menyebabkan resistensi insulin). Berdasarkan usia subjek penelitian didapatkan subjek dengan usia $<45$ tahun adalah 6 orang $(3,94 \%)$ dan usia $>45$ tahun adalah 146 orang (96,06\%). Hal ini sejalan dengan penelitian Radio Putro dimana subjek dengan usia $<45$ tahun adalah 6 orang dan $>45$ tahun adalah 24 orang dengan odds ratio (OR) 9,3. ${ }^{10} \mathrm{Hal}$ ini menunjukkan bahwa orang yang berusia $>45$ tahun mempunyai risiko 9 kali untuk terjadinya DM tipe 2 dibandingkan dengan yang berusia $<45$ tahun. Selain itu teori juga mengatakan bahwa risiko DM tipe 2 meningkat seiring dengan bertambahnya usia terutama usia diatas 45 tahun.

Variabel yang diteliti pada penelitian ini adalah tekanan darah, lama menderita diabetes dan LFG. Berdasarkan hasil analisis bivariat menggunakan spearman's correlation antara tekanan darah dengan LFG didapatkan bahwa ada hubungan yang bermakna $(p=0,000)$. Hal ini sejalan dengan penelitian yang dilakukan oleh Nurlaili Farida yaitu seseorang dengan hipertensi mempunyai kemungkinan untuk menderita kerusakan ginjal 16 kali lebih besar dibandingkan dengan orang yang tidak hipertensi. ${ }^{11}$ Penelitian lain juga membuktikan bahwa hipertensi merupakan salah satu faktor yang memperburuk fungsi ginjal disamping faktorfaktor lain seperti proteinuria, penyakit ginjal, hiperglikemia, hiperlipidemia dan beratnya fungsi sejak awal. Selain itu berdasarkan penelitian di RS Advent Bandung dari 70 orang pasien yang dilakukan inisiasi hemodialisa di ruang hemodialisa, ada sebanyak 57 penderita (81\%) yang mengalami hipertensi. Dari 57 penderita ginjal kronis dengan inisiasi 
hemodialisa, ada 20 penderita (35\%) yang mengalami hipertensi volume dependen, sedangkan 37 penderita lainnya (65\%) menggunakan obat-obatan antihipertensi. ${ }^{12}$ Dilihat dari arah hubungan antara tekanan darah dan LFG adalah negatif (terbalik) yang berarti semakin meningkatnya tekanan darah maka LFG semakin rendah, hal ini sesuai dengan studi pada 20 pasien nefropati diabetik dimana menunjukkan korelasi yang bermakna antara tingginya tekanan darah sistolik dengan penurunan LFG. Penelitian lain juga mendapatkan bahwa kecepatan penurunan fungsi ginjal lebih berkorelasi dengan peningkatan tekanan diastolik.

Untuk hubungan antara lama menderita diabetes dengan LFG berdasarkan hasil analisis bivariat spearman's correlation didapatkan bahwa tidak ada hubungan yang bermakna ( $\mathrm{p}=0,971$ ). Jika dilihat pada tabulasi silang, subjek terbanyak terdistribusi pada kategori 5-15 tahun dimana terdapat 32 orang yang mengalami kerusakan ginjal dengan penurunan LFG sedang (derajat 3) dan kategori $<5$ tahun dengan penurunan LFG berat terdapat 18 orang. Hal ini berbeda dengan penelitian yang menyebutkan bahwa kerusakan ginjal jarang terjadi pada 10 tahun pertama menderita diabetes dan biasanya akan terjadi pada lama menderita diabetes 15-25 tahun. Sedangkan untuk orang-orang yang hidup dengan diabetes lebih dari 25 tahun memilki risiko menderita gagal ginjal sebanyak 79\%. Tidak terdapatnya hubungan antara lama menderita diabetes dengan LFG dikarenakan laju filtrasi glomerulus tidak hanya bergantung pada lamanya menderita diabetes melainkan ada faktor lain yang mempengaruhi fungsi ginjal misalnya hipertensi.

\section{SIMPULAN}

Hasil penelitian ini ditemukan bahwa ada terdapat hubungan yang bermakna antara tekanan darah dan laju filtrasi glomerulus. Dengan arah hubungan negatif yakni semakin tinggi tekanan darah maka laju fitrasi glomerulus semakin rendah. Selain itu pada penelitian ini juga ditemukan bahwa tidak terdapat hubungan yang bermakna antara lama menderita diabetes dan laju filtrasi glomerulus.

\section{SARAN}

Diabetes Melitus merupakan penyakit yang tidak dapat disembuhkan sehingga perlu adanya pengawasan terhadap kadar gula darah, tekanan darah dan pengaturan pola hidup serta melakukan upaya pencegahan terjadinya komplikasi kronik.

Selain itu untuk penelitian selanjutnya diharapkan melakukan skrinning terhadap penggunaan obat anti hipertensi dan dilakukan penelitian lebih lanjut di masyarakat agar generalisasi hasil penelitian pada populasi lebih baik.

\section{RUJUKAN}

1. American Diabetes Association. Diagnosis and classification of diabetes mellitus. Diabetes Care. 2010 [cited 2013 Sep 09]. Available from: http://www.ncbi.nlm.nih. gov/pmc/articles/PMC2797383/?report=reader\#.

2. Purnamasari D. Diagnosis dan klasifikasi diabetes melitus. Dalam: Alwi I, Setiati S, Setiyohadi B, Simadibrata M, Sudoyo AW, editor. Buku Ajar Ilmu Penyakit Dalam, jilid III. Ed ke-5. Jakarta: Interna Publishing; 2009. hlm 1880-3.

3. Konsensus Pengelolaan dan Pencegahan Diabetes Melitus Tipe 2 Di Indonesia 2011. Agung P, Ari S, Askandar T, Sri M, Soni W. Universitas Airlangga: 2011.

4. International Diabetes Federation. One adult in ten will have diabetes by 2030. 2011 [cited 2013 Sep 15]. Available from: http://www.idf.org/media-events/pressreleases/2011/diabetes-atlas-5th-edition. 
5. American Diabetes Association. Diabetes statistics. 2011 [cited 2013 Sep 14 September]. Available from: http://www.diabetes.org/diabetes-basics/ statistics/?loc=db-slabnav.

6. Suyono S. Diabetes melitus di Indonesia. Dalam: Sudoyo AW, Setiyohadi B, Alwi I, Simadibrata M, Setiati S, editor. Buku Ajar Ilmu Penyakit Dalam, jilid III. Ed ke-5. Jakarta: Interna Publishing; 2009. hlm1873-79.

7. Awad N. Gambaran Faktor Risiko Pasien Diabetes Melitus Tipe II Di Poliklinik Endokrin Bagian/SMF FK-Unsrat RSU Prof Dr. R. D. Kandou Manado Periode Mei 2011 - Oktober 2011. Jurnal e-Biomedik. Maret 2013;1(1):47-8

8. Permana H. Pengelolaan Hipertensi pada Diabetes Melitus Tipe 2. Bandung: Sub bagian Endokrinologi dan metabolisme Bagian Ilmu Penyakit Dalam, Perjan RS Dr Hasan Sadikin / Fakultas Kedokteran Universitas Padjadajaran.

9. Chodijah S. Hubungan Kadar Gula Darah Puasa dengan Jumlah Leukosit pada Pasien Diabetes Melitus dengan Sepsis [skripsi]. Manado: Fakultas Kedokteran, Universitas Sam Ratulangi; 2013.

10. Wicaksono RP. Faktor - faktor yang berhubungan dengan kejadian diabetes melitus tipe 2 di polilklinik penyakit dalam RS DR. Kariadi [karya tulis ilmiah]. Fakultas Kedokteran, Universitas Diponegoro; 2011.

11. Muhajir NF. Hubungan antara hipertensi dengan kejadian gagal ginjal kronik di bagian rawat inap penyakit dalam RSUD Panembahan Senopati [karya tulis ilmiah]. Yogyakarta: Universitas Ahmad Dahlan; 2010.

12. Benyamin T, Melati W, Salawaney. Hipertensi pada penderita gagal ginjal kronik saat inisiasi terapi hemodialisa di renal unit RS Advent. Bandung: RS Advent; 2008. 